\title{
Marketing Communication Strategy Using Instagram to Increase The Selling Achievement
}

\author{
Yoto Widodo \\ Universitas Veteran Bangun Nusantara \\ Sukoharjo, Indonesia \\ yotowdd@yahoo.com
}

\author{
Ika Diah Oktaviani \\ Universitas Veteran Bangun Nusantara \\ Sukoharjo, Indonesia \\ ikadiahoktavianii@gmail.com
}

\begin{abstract}
Nowadays social media use has become more widespread, many societies that use social media as business media are often being called online businesses. Racingmerch201 as one online store that markets products, has special strategies to increase sales to be able to keep up with very tight online business competition. Communication markets using social media has changed the conventional marketing system to modern (online) and market activities can be estimated more widely. Racingmerch201 selects an instagrams social media type as a marketing tool.The purpose of marketing communications strategies carried out by the Racingmerch201 is to increase sales through the social media Instagram. The research methods used are qualitative descriptive. Techniques of data collection were carried out through in-depth interviews and direct observation of marketing communication strategies. The results of the study showed that the marketing communication strategies applied to the Roundmerch201 are using the internet, especially social media charts. The chart is a sharing of advertising promotion, sales promotion, individual sales, direct sales, and publicity. The use of social media platforms to increase sales of products and increase sales is a very significant sale. Instagram can illustrate the limitations of meetings between product providers and consumers, thus making this media the right marketing medium to bridge information exchange processes and long-distance buying and selling transactions.
\end{abstract}

Keywords: instagram, marketing communication strategy, racingmerch 20

\section{INTRODUCTION}

Instagram is a phenomenal social media in 2015. Launched in 2010, as a medium of communication, Instagram on how it works is photo / image-based media. So with Instagram social media, the users can share photos with friends and write comments on uploaded photos. In 2014 Instagram active users reached 300 million people, this number defeated social media twitter which first appeared on social media. In September 2013, Instagram users were only around 150 million. The number of users reached 300 million, Instagram beat Twitter. Hurry, December 12, 2014 [9].

Instagram as a social media photo sharing has the basics in its use. According to Kjell Halvor Landsverk [7]. Instagram usage includes:

1). Feed, in this feature usage can see what friends have uploaded that have been followed.

2). Popular "tab", the popular "tab" is used for users to view photos uploaded by other users and in this feature users will see the photos that are most liked every time. If you want to see something more specific, write it in the username and hastaghs column.
3). News and Update, this instagram is when we interact with friends who are followed through photos uploaded, with likes, or comments and bring up notifications on our Instagram that generate information for Instagram users.

4). Like and Comment, like or comment on Instagram is an appreciation and appreciation for Instagram users. If the user is interested in a photo, we can like the photo by giving a double tab and can give comments if you want to interact with other users.

5).Your profile, profiles can be seen in squareicon, on the saved profile photo files that users have uploaded.

6). Post, Posting is a term or language when uploading photos. The photos to be uploaded can be given a layer to make them look attractive using the features provided by Instagram.

Business people who use Instagram accounts to promote the merchandise are usually the first target buyers are people who are close to them, by having an Instagram online shop account can tell friends around them. Start by word of mouth while showing the online shop account in question. With Instagram, of course, the easier sales of goods, because they can show photos of their merchandise completely. This is also what makes one of the reasons this t-shirt business owner utilizes instrumental, with the account name Racingmerch201.

Marketing communication is a marketing activities that share an information, influence or persuade, and to remember the targets market of the company and their product in order to receive, buy and be loyal to the product that is offered of a company. [1], [2]. Because of the marketing science development, now the purpose of communication is not longer limited to encouraging the first purchases, but also ensuring satisfaction to encourage purchases so that it increases the likelihood of repeated purchases and these purchases become loyal customers. Communication is needed to inform the consumers regarding the availability of an offer, the unique benefit of the offer, where and when it can be obtained and used by the offer [3].The more competitive the business environment, the more it is necessary for the company to segment the market and the more important it is for the company to align its marketing mix with the chosen target market so that it can effectively allocate resources while providing the highest value to its customers. Segmentation is very important for business success that adopts a segmentation approach to improve its performance [4].

1

Before a company conducts a series of promotions, there are three stages of marketing communication strategies 
that need to be carried out by the company, namely determining segmentation, targeting, and positioning. 1).Segmentation is identifying specific groups in the market whose wants and needs can be met by the company's products. Segmentation divides groups based on demographic, geographical, demographic, psychographic, behavioral and benefit aspects [6]. 2). Targeting is to choose one or several consumer segments that will be the focus of marketing and promotion activities.3).Positioning is a communication strategy that relates to how audiences place a brand or company product in their brain, so that the audience has a certain assessment. Positioning strategy is a strategy that seeks to create unique differentiation in the minds of target consumers, so that the image or brand image is superior to other brands or products [1].

Based on the background above, the aims of this study are as follows:

1).Knowing and describing how Racingmerch201's marketing communication strategy in increasing sales through social media.

2).Knowing and describing the use of Instagram social media in marketing communication activities.

Chart

Main Mapping

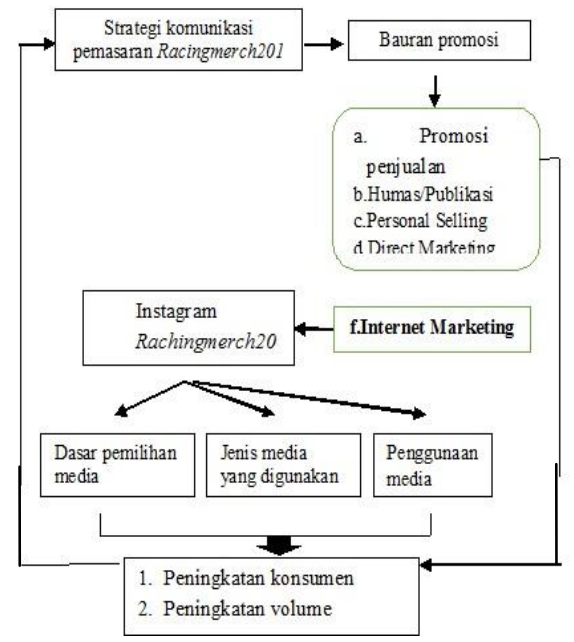

\section{METHODS}

This research was conducted at Racingmerch201 distro located in the village of Menggungan rt 3 / rw 3 Sawahan, Ngemplak District of Boyolali for 2 months from 24 September 2017 to 24 October 2017.This study uses a descriptive research method with a qualitative approach. Descriptive qualitative research methods are used by researchers to obtain data and present data optimally and comprehensively in accordance with the theory used. In this study, researchers used purposive sampling type sampling techniques to obtain the data needed and in accordance with the type of research [8].

The selection of informants has been determined, namely someone who is considered to have information in accordance with the needs of the researcher. Among others; owner of Racingmerh201 (Wahyu Budi Yuwono), the admin who manages Instagram Racingmerch201 accounts (Heriawan Bobby), and consumers who use Rachingmerch201 products (Febrian Antony, Tyas Panggih Mahardika and Maulana Yusuf Bachtiyar).

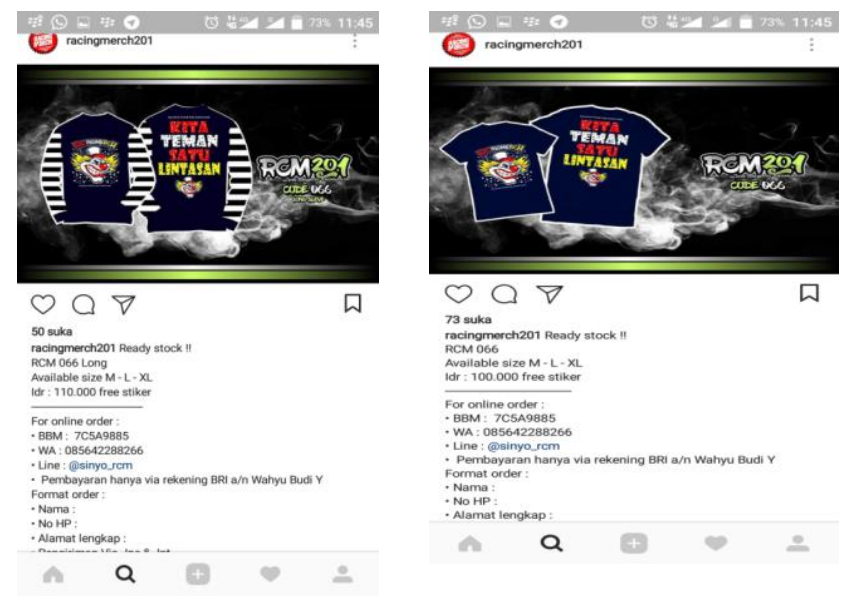

Picture: Shirt that was posted on Instagram

\section{DISCUSSION}

\section{A.Business Profile of Racingmerch201 Distro}

Racingmerch201 was established in 2013, by Wahyu Budi Yuwono, located in the village of Menggungan rt 3 / rw 3 Sawahan, Ngemplak district of Boyolali. Starting from a friend who ordered a shirt then wahyu had the idea to make a racing shirt and set up his own convection. With the help of 2 of his friends wahyu runs this t-shirt business with a passion, confidence and hope to be able to lift and market his own work more broadly. Approximately the first 6 months racingmerch201 only receives orders from friends around or marketing only by word of mouth. Not only creative in creating unique t-shirt designs, wahyu is also creative in marketing his products through instagram social media to provide services so that he can make purchases directly through his official account.

Sales through social media aim to make it easier for consumers to choose their products and directly buy the products they need. Consumers are also not far away in finding and buying rachingmerch 201 products that have stores. This will later increase the number of production and sales of racingmerch products. An instragram account can help the rachingmerch201 company expand the consumer network, because every consumer can access instagram from this rachingmerch201.

The target of the rachingmerch201 product is general which means that all people who like the world of racing (racing) around solo and outside solo will be the target in their t-shirt products. The use of instagram social media as a marketing tool is the right media to reach various groups. This can be seen from the general public who now have a majority of social media accounts. The price of products offered by rachingmerch201 is still affordable, which is 
around rp. 80,000, - up to rp. 110,000, - with good product quality.

\section{B.Marketing Communication Strategy By Racingmerch201}

Marketing communication strategy is a careful planning of marketing as an effort to convey messages to the public, especially the target consumers about products marketed through the promotional mix and analyze segmentation, targeting and positioning. For that before carrying out marketing communications racingmerch201 analyzes the important factors that will be used to make the stages of planning a marketing communication strategy which includes segmentation, targeting and positioning in achieving its objectives. In addition racingmerch201 also tries to find out the purpose of communication and the implementation of marketing communication strategies that will be carried out using a promotional mix in the form of advertising, sales promotion, individual sales, direct selling, and internet sales.

Of the five communication tools racingmerch201 did not use individual sales promotions because in selling tshirts already had their respective duties. Racingmerch201 emphasizes more on the use of internet sales promotion because it feels more reaching consumers widely. Racingmerch201 in the last 1 year Actively Utilizes instagram social media as a marketing tool and provides services for buying and selling transactions by communicating between sellers and buyers so that they can share about sales products.Through of photo posting on instagram racingmerch201 social media, customers can find out about new products more quickly than if they had to visit a physical form that stores similar products. The cost and energy spent to get to the shop is certainly far greater than just seeing the catalog on social media.

\section{C.Use Of Instagram Social Media In Marketing \\ communication.}

Instragram's social media is one of the emerging media used for all people, ranging from teenagers, adults, parents, and even children to follow the development of social media that has a wider network than other social media. judging from the development of social media racingmerch201 uses instagram social media as a means of marketing activities through the internet. the instagram account shows the use of feature features that service providers have provided as a means of promotion and communication with consumers. in 2016 racingmerch201 marketing activities were more intense, it was seen in the activity of using information in the form of text and photos that were carried out regularly.

Since 2015 racingmerch201 has known about the use of social media as a marketing tool, so that in the same year racingmerch201 began making several accounts on social media to support marketing activities carried out. however, based on observations and interviews that have been carried out it is known that the use of instagram social media in marketing activities only began in 2016. starting in 2016 the owners chose to use instagram social media to further increase their sales. because according to him the use of instagram in the marketing media experienced a fairly rapid development compared to the previous one using facebook social media, the turnover that was received was around $50 \%$. but when using instagram social media turnover experienced an increase of up to $80 \%$. even racingmerch 201 often gives promos in the form of price discounts or free shipping services, this is also very helpful in the marketing process of racingmerch201 shirts.

\section{CONCLUSION}

The stages of marketing communication strategy are, determining the purpose of marketing communication, determining segmentation, targeting, and positioning. Racingmerch201 conducts a promotional mix in order to know, process and evaluate things that can make its marketing communication strategies more effective. In the promotion strategy, Racingmerch201 is one that does not use individual sales because sales are done in teams or together. The promotion carried out by Racingmerch201 emphasized more on the use of social media, especially Instagram.

The operation of Instagram social media which is a software application is an advantage for Racingmerch 201. This is considered flexible because wherever and whenever maintenance activities can be carried out. Even though it only has limited time and high activity, marketing activities on social media can still be done continuously.Social media facilities that support marketing activities, make marketing strategies work well and on target. Besides that, Istagram is a social media that many people already know about. So that the media is the right media used by Racingmerch201. With relatively low promotional costs and uncomplicated operations that have a wide range. Of the various built-in supporting features of Instagram, the most frequently used feature in each post is Racingmerch201 which is a photo title feature (caption), and hashtag (\#). To bind consumers, Racingmerch201 makes edited image postings and uses models.

\section{REFERENCES}

[1] Tjiptono, Fandi,, Strategi Pemasaran, Yogyakarta, Andi Offset, 2001

[2] Kotler Philip, Kevin Lane Kaller, Manajemen Pemasaran Edisi Ketiga Belas Jilid 2. Jakarta: Erlangga, 2009.

[3] Sulaksana, Uyung, Komunikasi Pemasaran, Yogyakarta, Pustaka Pelajar, 2003.

[4] Kotler Philip, Kevin Lane Keller, Manajemen Pemasaran Jilid 1. Jakarta: PT. Prenhalindo, 1997

[5] Soemanagara, K. J., Marketing Communication . Jakarta: PT. Buana Ilmu Populer (Kelompok Gramedia), 2006.

[6] Morisson, Periklanan : Komunikasi Pemasaran Terpadu, Cetakan Pertama, Jakarta: Kencana Prenada Media Group, 2010.

[7] Salbino, Sherief, Buku Pintar Gadget Android untuk Pemula, Jakarta, Kunci Komunikasi, 2014.

[8] Krisyantono, Rachmat, Teknik Praktis Riset Komunikasi. Jakarta: Prenada Media, 2006.

[9] http://www.indoberita.com/jumlah-pengguna-capai-300-jutainstagram-kalahkan-twitter/7823/ di akses pada 16 Januari 2018 pukul 21.00 WIB. 